\title{
The Outcome of Directive 2009/73/EC Amendment on EU's Natural Gas Security
}

\author{
Javad Keypour
}

ATEF Think Tank

Tehran 14738-95773, Iran

E-mail: jakeyp@taltech.ee

Abstract: The European Commission has proposed an amendment on the Gas Directive 2009/73/EC to broaden the applicability of the Directive to all gas pipelines from/to the EU including Nord Stream 2. This research focuses on the question of whether the amendment can really boost EU's natural gas security, by hindering Nord Stream 2. Thematic analysis has been employed as the methodology for analyzing collected data from primary and secondary sources, and relying on a legal and political analysis. The research findings show that although the amendment hinders Nord Stream 2, it also affects the operation of the existing interconnectors adversely. It also declines investors 'tendency for planned pipelines, which lowers EU's energy security. Moreover, empowerment of the Commission in the proposed amendment curtails Member States ' plans to enhance their energy security. In addition, the security analysis of the research shows that Moscow's ability to take advantage of its "energy weapon" is being defied because of dependence on European technology and finance, particularly under the sanction condition. Therefore, restraining Russian gas in the European market will not result in a higher level of energy security since reliable and affordable alternatives are not so available. Hence, all four elements of energy security - that is, affordability, availability, accessibility, and acceptability-are jeopardized by the proposed amendment. The current study concludes that although the amendment is expected to boost the energy security of the Union, it may now turn into a threat per se.

Keywords: energy security, Gas Directive, Russia, Third Energy Package, US LNG 


\section{Introduction}

The security of energy supply has been among the European priorities since the creation of the European Coal and Steel Community (ECSC) in July 1952 (Coq \& Paltseva, 2009; Kerikmäe, 2000). EU's attempts at addressing energy security concerns in official documents is reflected in the White Paper on Energy Policy, published in 1996, which points out "diversification of supply" and "competitiveness" (Belyi, 2003). This led to the First, Second and Third Energy Package (TEP) legislation in the EU. However, the growing rate of dependence on external natural gas resources has reached to $74.32 \%$ in 2017 , which mainly comes from Russia (Eurostat, 2018). Therefore, the Commission has tried to revise its laws and regulations to decrease energy dependence to Russia.

When it comes to natural gas, the main part of the TEP is the Gas Market Directive 2009/73/EC, or simply the Gas Directive. Market liberalization, reducing monopolistic practices of energy companies and growth in competitiveness and general "unbundling" are the main aims of the Gas Directive (Funtini, 2015). However, the Gas Directive failed to hinder Nord Stream 2 (NS2), which was recognized as a threat to EU's energy security by some of the MEPs (Tomić, 2018). Therefore, the Commission proposed an amendment to the Gas Directive to support EU's energy security via hindering NS2. The amendment was ratified in the Commission after a compromise was reached between France and Germany in February 2019 and sent to the European Parliament (Proposal 6351/19/COR1).

The purpose of this study is to evaluate the outcomes of the proposed amendment of the Gas Directive from an energy security viewpoint. This is important because although the aim of the amendment was set to be boosting the energy security of the Union, it may now turn into a threat per se. Hence, evaluation of the outcomes of the amendment is essential in order to guarantee being in line with the primary goals of the TEP.

The Gas Directive or the amendment have drawn the attention of some scholars already. Talus (2017) made a legal review on the amendment in contrary to EU law. In addition, Hancher and Marhold (2019) studied its compatibility with EU competences. Romanova (2016) discussed the encounter between Russia's foreign energy policy and the TEP. Despite these works, the impact of the amendment on the energy security of the Union has not been studied before. The other novelty of this research is due to its holistic approach in energy security definition. In fact, the four elements of availability, acceptability, affordability, 
and accessibility have been considered, instead of focusing exclusively on the security of supply. Given what was discussed above, the research aims to show the political and legal consequences of the amendment implementation. The research question that this work aims to address is: How will the recently proposed amendment of the Gas Directive affect the EU's natural gas security?

The main claim of the paper is that the proposed amendment of the Gas Directive will threaten the energy security of the EU. In order to examine the claim, the impacts of the amendment have been discussed from both political and legal perspectives, posing two pertinent research questions. First, how does broadening the applicability of the Gas Directive to all gas pipelines from/to Europe restrain other external sources of natural gas for the EU? In fact, the research tries to show how the European energy security will be threatened if other gas suppliers of Europe are going to be affected by the amendment. The second question is: How does curtailment of the Russian gas in the EU natural gas market affect the energy security of the Union in the current situation? Here, another analysis will show the extent to which it is possible to reduce dependence on Russian gas in practice, and how much it is in favor of EU's energy security as the amendment follows. These two questions will lead to an answer to the main research question.

This study employed a theoretical thematic analysis to both research questions since it is a flexible method appropriate for usual problems in real life (Guest et al., 2012). Reliability of the method has been boosted by using data from diverse resources and multiple researchers' works. Therefore, data preparation was carried out on the basis of both primary and secondary sources as the first step. In other words, while the EU's official legal energy policy documents have been studied as the primary sources, analytical and statistical reports, as well as books and research papers, have been studied as the secondary ones. Then, as the theoretical framework of this research, initial codes were generated and analyzed considering the Copenhagen security school's concept of 'securitization'. As the next step, the pertinent coded data was classified and clustered to form themes. After that, the collected themes and data were reviewed to assure the existence of a meaningful connection between them. Finally, the themes were placed in a logical order to achieve a clear answer to both research questions and the main one.

The structure of the paper is as follows. In Section 2, the Copenhagen school is presented as the theoretical framework used for securitizing the energy concept. Then, the methodology is discussed in more detail. Relevant parts of the TEP and the amendment will be pointed out in the results section in order to portray a clear state of the art. The discussion presents both a legal and political analysis 
on the issue of Russia-EU natural gas relations considering what the amendment tries to change. The conclusion recaps the discussion relying on all four elements of the energy security concept and aims to show how all these elements are adversely influenced by the amendment. This shows that the amendment will restrain the EU's accessibility to affordable and accessible energy resources and, as a result, will decline EU's energy security.

\section{Theoretical framework}

Traditionally, the security concept has been associated with the state and threats against sovereignty, particularly in the realist school. Therefore, military power has been the most important measure to make a sovereign state secure. In addition, "security policy consists of the use of armed forces - the military and the police-to free the state and its citizens from threats" (Huysmans, 1998, p. 487). However, the advent of new threats particularly at the end of the Cold War era showed an incapability of the traditional approaches to cover all kinds of threats. In the late 1980s, the Copenhagen school emerged and tried to expand the idea of security in order to cover new threats, including not just military issues, but a wide range of political and social, economic and environmental problems. It also attempted to accept non-state actors as the agents of security in the analysis (Buzan et al., 1998).

The Copenhagen school believes that security is a special part of politics which is applicable in different aspects. However, it does not mean that any political topic can be simply recognized as a security issue, but instead, any public issue can be located on the spectrum, such as these given below:

1) Nonpoliticized: Issues that the state does not deal with, nor need public debate and decision;

2) Politicized: Issues which are part of public policy, demanding government decision and resource allocations or maybe some other form of communal governance;

3) Securitized: Issues that are presented as an existential threat, requiring emergency measures and justifying actions outside the normal bounds of political procedure (Buzan et al., 1998).

Accordingly, a hypothetical actor takes an issue out of what under those conditions is "normal politics" and makes it "securitized" in a process called "securitization". Moreover, security is an intersubjective issue rather than 
objective or subjective in the Copenhagen school. This means that one cannot securitize an issue individually but it needs to be constructed socially. As a result, the actor legitimizes the securitization process via speech act, for instance. The issue is securitized when the audience of the security speech act accepts it as an existential threat to a shared value (Buzan et al., 1998). In other words, as Waever argues, "security is a kind of 'discursive act' as a 'speech act', by which a security issue is labeled as 'important' and 'urgent', that 'legitimizes the use of special measures outside of the usual political process to deal with it" (Özcan, 2013).

Although the Copenhagen school does not consider energy security as an independent security dimension, its importance is penetrated in different facets, including political, military, economic and environmental ones (Belyi, 2003). Moreover, the rise of oil prices in late 1973 set the stage for the securitization of the energy concept in which states followed measures to guarantee meeting their energy demand.

Despite the fact that energy has been already securitized as a concept, there is no unanimously accepted definition to the 'energy security' concept and more than 45 ones have been recognized by Sovacool (2011). However, Maleki (2017) has tried to combine most of the available definitions to introduce a comprehensive one. Thus, the energy security concept can be determined based on four elements of availability, accessibility, affordability, and acceptability, as they are explained in Table 1 and will be used in the current research.

Table 1. Energy security elements according to Maleki, 2017

\begin{tabular}{|l|l|}
\hline Element & Explanation \\
\hline Availability & $\begin{array}{l}\text { How durable the resource is, in order to make it available in the } \\
\text { future }\end{array}$ \\
\hline Accessibility & Having access to the energy resources should be easily possible \\
\hline Affordability & $\begin{array}{l}\text { Equitable price based on the transparent pricing method and } \\
\text { minimum volatility }\end{array}$ \\
\hline Acceptability & $\begin{array}{l}\text { Finding a model which guarantees sustainability and continuity of } \\
\text { long-term energy development }\end{array}$ \\
\hline
\end{tabular}




\section{Methodology}

This study employed a theoretical thematic analysis for both research questions. Similar to many other qualitative research methods, the first step is data preparation (Gibbs, 2008). The main data source for this research are various official documents, books, published papers and think tank reports. While the first ones are classified as the primary resource, the rest is known as the secondary ones. Thus, official EU documents regarding energy policy have been selected, including the Gas Directive and the proposed amendment as the main part. These legal documents are required to survey the first research question and for performing the legal analysis. Official statistics on alternative energy resources for the Union as well as primary or secondary documents which imply the level of mutual dependency between Europe and Russia have been gathered as well. Analytical reports of think tanks, which projected the future of the EU natural gas market, have been chosen as the second part of the research.

In the second step, initial codes were generated. In this phase, the found data was organized systematically and in a meaningful way. In fact, coding helps to reduce large amounts of data into small chunks of meaning. Coding can be done in two different ways: inductively and theoretically. Inductive thematic analysis is used in cases where there are no previous studies dealing with the phenomenon, and therefore the coded categories are derived directly from the text data while in the 'theoretical' thematic method, analyzing the data is done with addressing specific research questions in mind (Vaismoradi et al., 2013). Since the current research was driven both by a theoretical interest and a couple of clear research questions, the approach is theoretical.

Searching for themes comes in after the code generation. After all the data was coded, they were gathered into more and more abstract codes until a common theme or a pattern was represented by a cluster of them (Bergström, 2010). In other words, a theme is a pattern that captures something significant or interesting about the data and/or research question (Maguire \& Delahunt, 2017). Hence, pertinent codes were placed under one theme in the legal documents in order to connect the impacts of the amendment on the interconnectors from third countries to the EU territory. The same was performed in search of the answer for the second research question through the rest of the abovementioned documents. This sets the stage for generation of themes on alternative energy resources for Europe as well as bilateral dependency between Russia and the European Union in the energy field. Data and themes were reviewed to prove the existence of a sensible and meaningful bilateral connection. All the data should 
support their theme and themes should be assessed for whether they work in the context of the entire data set as well.

As the last step, the themes were arranged in an order which would clarify the answer for the research question (Gibbs, 2008). In the current research, the themes were connected to each other using a theoretical framework to show how the four main elements of energy security will be affected by the amendment, considering the legal and political themes.

Thematic analysis has its own pros and cons. For instance, it is very flexible since it is not tied to a particular epistemological or theoretical perspective, unlike many qualitative methodologies. Furthermore, it is systematic, which makes it suitable for interpretation of usual problems in real life, such as issues of energy security (Guest et al., 2012). Moreover, since energy security has social, political and technical components, having a systematic approach in performing research is vital (Chernyak et al., 2018; Sorrell, 2007).

The main weakness of the thematic analysis is low reliability due to a wide variety of interpretations from multiple researchers (Guest et al., 2012). In this research, the counter-argument in the core themes have been adopted by surveying a variety of primary and secondary resources from diverse resources and multiple researchers' works, simultaneously. For instance, the energy dependency between Russia and Europe has been surveyed according to the statistics and analysis from both Russian and Western resources.

\section{Results and findings}

The Third Energy Package was planned to restrict the dominance of Gazprom and put an end to its adaptation strategy through downstream integration in the EU (Boussena \& Locatelli, 2013). The Gas Directive as the heart of TEP was designed and legislated to reduce the possibility of the dominance of certain companies by increasing the competition between external suppliers over EU energy market (Siddi, 2018). As a result, the 'Gazprom clause' in the TEP limits the ownership of energy distribution assets within the EU by the external energy providers, which ultimately constrains Russia's destructive dominance in the EU energy market (Goldthau \& Sitter, 2014). Along with the current version of the Gas Directive, the urgency of the Commission to adopt the amendment can be largely attributed to NS2 (Wilson, 2018). In fact, the Directive amendment wants to shoot down NS2 as it is believed that the pipeline is against EU's 
energy security since it will diminish Ukraine as the traditional route for Russian gas towards Europe. All the efforts have been made because EU considers dependence on Russian gas as a threat (Henderson, 2015).

Legislation of the Gas Directive has raised a question over its applicability and relevance regarding NS2, a pipeline connecting Russia to EU's internal energy market through Germany. NS2 has been recognized as a Russian political measure to undermine Ukraine as the traditional transit route. The situation became more critical when it became clear that the Gas Directive is not applicable to it, and as a result, it is not possible to hinder the construction of the pipeline. In fact, the pipeline could not be considered as an 'interconnector' according to the Gas Directive, since an interconnector should span between EU Member States (Talus, 2017). As the Commission claimed the existence of a 'legal void' or a 'conflict of laws' in this case (Wilson, 2018), it asked for a mandate to negotiate an intergovernmental agreement (IGA) between the EU and Russia on the operational aspects of the pipeline. However, most of the Commission's claim was rejected later by the Legal Service of the Council of the EU, which explicitly declared the absence of a legal rationale for the mandate. Therefore, the Commission launched the amendment of the Directive in order to expand its applicability to external pipelines and to create a legal rationale for a mandate (Yafimava, 2017). The latest proposed amendment following the France-Germany compromise was concluded on 12 February 2019.

The main baselines of the TEP proposed amendment can be categorized into four main components:

1) Expansion of the definition of "interconnectors" to the territorial waters of the Member States and covering the pipelines from third countries to an EU Member State (Article 2);

2) Empowerment of the Commission in decision making, especially for negotiation with third countries, derogation or expansion of pipelines from Directive (Articles 36, 49, and 49aa);

3) Accentuation of the role of the states who may be affected by interconnectors that span EU Member States' border and third countries (Articles 34, 36 and 49);

4) Clarifying the condition of derogation and exemption (Articles 36, 49, 49a and 49aa)

According to Article 2(17) of the Gas Directive, 'interconnector' means "a transmission line which crosses or spans a border between the Member States for the sole purpose of connecting the national transmission systems of those 
Member States". However, it is expanded to a new definition in amendment to Article 1(1), which says:

transmission line which crosses or spans a border between Member States for the purpose of connecting the national transmission system of those countries or a transmission line between a Member State [...] and a third country [...] up to the territory [...] of the Member States or the territorial sea of the Member State [...].

According to the amendment, derogation should not be for more than 20 years. It can be made in order to enable recovery of investment or due to reasons of security of supply while not being detrimental to competition. Therefore, existing pipelines between the EU and North Africa or the UK in post-Brexit will be affected. Particularly, the two main older African routes, Maghreb and Transmed, were constructed in 1996 and 1983, respectively, and even Greenstream or Medgaz, which became operational in 2004 and 2010, would probably not be subjected to a 20 -year derogation relying on the need for "recovery of the investment made" (Talus, 2019). Connectors between the UK and the EU will have the same legal status in post-Brexit. Details on AfricaEurope pipelines are shown in Figure 1.

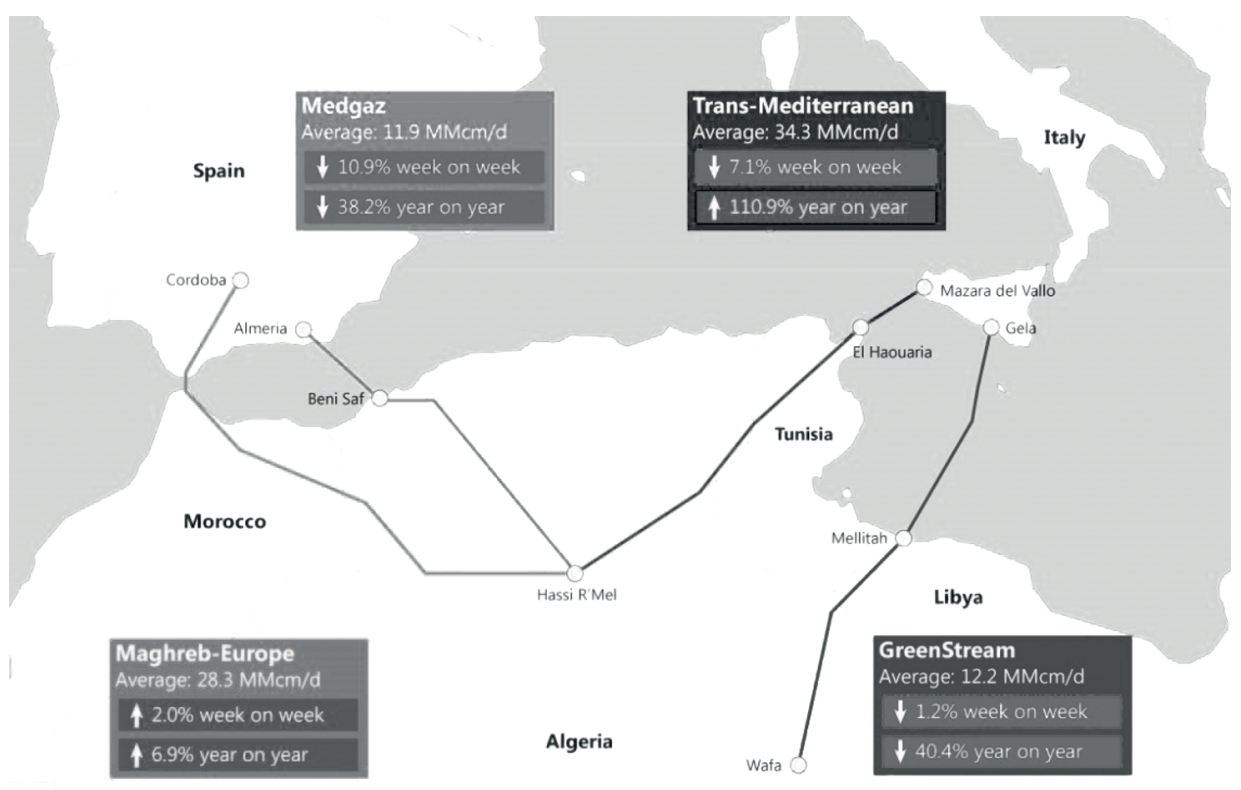

Figure 1. Africa-Europe pipelines (Ratcliffe, 2018) 
In addition, Article 49a of the proposed amendment says:

Where the gas transmission line [...] in question is located in the territory of more than one Member State, the Member State in the [...] territory of which the first [...] connection point with the Member States'network is located shall decide on a derogation for the [...] gas transmission line [...] after consultation with all concerned Member States.

Also, Article 36(5)(a) says:

Before adopting the decision, the national regulatory authority, or where appropriate other competent authorities shall consult: (a) the national regulatory authorities of the Member States the markets of which are likely to be affected by the new infrastructure; and (b) the relevant authorities of the third countries, where the infrastructure in question is connected with the Union network under the jurisdiction of a Member State and originates from or ends in one (or more) third countries.

In the other words, Articles 36, 49, 49a and 49aa of the amendment try to make some 'derogation' for the existing pipelines and 'exemption' for new ones, while different Member States are determined to be consulted. According to Article 36(9) of the Gas Directive, the EU Commission is the final authoritative body who determines whether the pipeline can be exempted.

Furthermore, the amendment has a retroactive approach toward all of the current deals and asks the states to revise them accordingly. It means that all types of under construction projects are the same, regardless of their progress level and how much money has been spent there. In other words, the amendment behaves similarly to new pipelines in the range from 'planned' to 'ready to operate' projects (Talus, 2019).

\section{Discussion and implications}

The outcomes of the Gas Directive can be discussed first considering the abovementioned four elements and unbundling as the backbone of TEP from the legal perspective. In addition, the implementation of the Directive amendment will result in some political impacts that will be discussed separately. 


\subsection{Legal analysis and discussion}

The current method for defining derogation and exemption in the amendment means a growth of uncurtaining for the investment. Legal results show that there is lack of an exclusive, clear criterion which defines "who the concerned Member States can be", in Article 49a. A similar condition can be seen about under-construction pipelines, since Article 36(5)(a) authorizes the Member States whose "markets are likely to be affected by the new infrastructure" to be consulted in building new pipelines. If this continues, the investors will be confused because of the multiplicity and ambiguity of the determining actors in making the decision for exemption or derogation. The investment will be affected also due to the retroactive approach of the amendment asking for revising the current deals. This uncertainty regarding the investment atmosphere is a threat to future projects and especially for energy security, since the affordability and availability of energy is going to be affected.

Implementation of the amendment for those pipelines, which enter the EU's territorial waters from a third country, is a little deceptive. According to the amendment, jurisdiction of the Directive will expand to the "territorial sea of the Member State". Thus, interconnectors from third countries to the territorial waters of Member States will be subject to the amendment because it is physically impossible to differentiate between their European part and the rest (Zbytniewska, 2019). Since the perspective of Turkey's accession to the European Union is still blurry, the Turkish Stream or any plans to export gas from the Eastern Mediterranean will be affected as well. This intricacy in the exemption of new pipelines is against EU's energy security in two aspects: it puts under doubt new pipelines and it gives a negative signal to the investors concerning other planned projects, which are both detrimental to the energy security of the Union.

Last but not least, the proposed Commission's empowerment in the amendment seems controversial from a legal perspective. The amendment practically gives the Commission exclusive external competence on the IGAs for the interconnectors from third countries; including its right to have the final say on both derogation and exemption (Hancher \& Marhold, 2019). This appears to be in contradiction with Article 194(2) of the TFEU where it is said the Union's policy on energy shall not affect a Member State's choice between different energy sources and the general structure of its energy (Talus, 2019). Also, it appears to violate the TFEU Article 194, which lists energy security as a shared competence of the EU and its Member States (Wilson, 2017; Kerikmäe, 2006). 
Political analysis shows that the amendment will threaten the affordability and availability of energy resources for the Union. This will lead to a lower level of energy security in the EU.

\subsection{Political analysis and discussion}

\subsubsection{Russian gas: is it "always" a threat?}

Despite the Western ideal dream to make a 'depoliticized' international energy trade, the goal seems still unachievable since energy is still not a "purely economic" phenomenon (Högselius, 2013). The implication of security analysis according to the Copenhagen school shows that Russian gas has been 'securitized' particularly after two Russia-Ukraine gas conflicts in 2006 and 2009. The EU's urgency to legislate the amendment, as was described in the results section, also attests to the securitization of Russian natural gas in the EU market, according to the Copenhagen security school. Some scholars even believe that the EU is negligent to the "fact" that Russia uses its energy resources as a security and foreign tool to influence its neighbors (Smith, 2009). However, the results of this research show that considering Russian gas as a threat should be interpreted cautiously, as will be explained below.

Although the EU is not yet ready to face a hypothetical interruption in Russian gas import (Ruban, 2013), such an event is not even so likely because Moscow does not like to be known as a capricious player in EU's natural gas. Despite all the geopolitical changes that have taken place over these 50 years, Gazprom claims that it has stayed "a reliable supplier of the vital resource for the partners in Europe" (Gazprom, 2015). This will be highlighted further, considering the fact that Russia did not extend the Ukrainian route problem to the gas routes, neither in 2006 nor in 2009 gas conflicts. A sudden cut in the gas flow will reduce Russia's reliability and, as a result, Russia's contract volumes and prices may decline significantly in the future by the clients, which is not desirable for Gazprom (Morbee \& Proost, 2010). Therefore, Moscow is cautious about the political usage of its gas exportation.

In addition, applying energy as a political advantage by Russia is not curtailed just due to the lack of Kremlin's tendency. In other words, Russia even cannot easily use the energy as leverage against the EU in the current situation due to different facts. First, possessing energy resources is not enough for this goal. For instance, more often than not, Russia has failed to achieve political concessions 
by using its energy resources as a "weapon" before. This is because the ability of an energy owner to use this "weapon" is highly dependent on other issues like the dominance on the energy infrastructure of the target state or the level of state resources monopolization. Even a historical survey shows that Russia has not been always successful in using its energy resources as a political measure in relation to the West (Stegen, 2011).

From another perspective, Russia-EU energy relation is one small piece of a bigger puzzle of bilateral economic relations - the 'inter-dependency'. In fact, if the EU relies on Russian gas, Moscow is also technologically and financially dependent on Europe. Moscow's dependency on the Western equipment in the upstream sector was between $60-100 \%$ shortly after the first round of EU sanctions in 2014 (Nikulina \& Kruk, 2016).

The same trend is discernible in the financial perspective. Statistics show that $46 \%$ of the Russian federal budget revenue came from oil and natural gas activities in 2018 (Minfin, 2019). Considering the fact that the EU is the main destination for up to $75 \%$ of Russian natural gas export and $68 \%$ of Russian exporting revenue (EIA, 2017), European gas market is irreplaceable for Russia. Even China cannot be considered as an alternative since the under-construction "Altai pipeline" from Russia to China is going to be fed from Western Siberian gas field, not the current fields which are used to feed European states (Lifan $\&$ Chengzhi, 2015). Figure 2 shows how oil and gas have a dominant role in Russian export revenues.

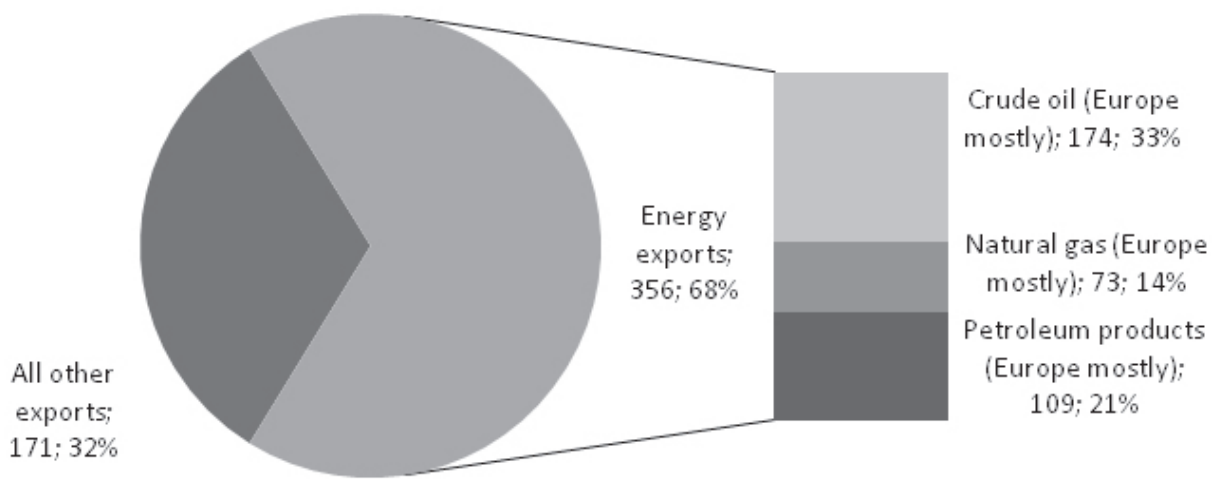

Figure 2. Russia gross export sales in 2013 in percentage and amount (billion USD). Statistics gained from EIA. 
In addition to Russia's dependency on EU, sanctions by the West and the oil price fall have weakened the Russian energy "weapon" as well. Selling the equipment applicable to deep-water drilling, shale oil extraction and extraction of oil from the Arctic zone is now forbidden according to the sanctions (EIA, 2017). Shortly after imposing sanctions against Russia, the consultancy IHS CERA estimated that the sanctions, if maintained, could cause a 25\% drop in Russian oil output by 2025 (Farchy, 2014). More optimistic resources believe that despite the outcome of the sanctions not being catastrophic, it will result in production decline in the next decade (Mitrova, 2018). According to a survey, sanctions have directly affected sanctioned state-controlled banks, oil, gas and arms companies in Russia. Obstacles for the Russian company Novatek to access US capital caused a 27 billion US dollars raised in needs for its Yamal LNG (Liquefied Natural Gas) project, and as a result, the Chinese National Petroleum Company (CNPC) took a 20\% share of the Yamal LNG (Russell, 2016). Moreover, the sanctions have hampered Russian oil industry's modernization and its capacity to generate income for Russia's overall modernization as well (Aalto, 2016).

The sanctions have not just influenced the oil and gas industry in Russia, but the whole economy. The overall negative effect on gross capital inflow over 2014-2017 is estimated at approximately 280 billion dollars. The estimated effect of the sanctions on GDP is also significant ( -2.4 p.p. by 2017, compared with a hypothetical scenario with no sanctions). The impact of fall in oil price has been even worse for the Russian economy: up to 3.3 times more than the sanctions (Gurvich \& Prilepskiy, 2015). This prevents Russia from continuing its aggression via energy resources.

Last but not least, contrary to the expectations of neoliberalist and neofunctionalist theories, this 'interdependency' has not been expanded to a higher level of 'complex interdependence' and therefore, tensions decline. In fact, neofunctionalism believes that cooperation between two states in one field always 'spills over' to other fields. Neoliberalism also believes 'spillover' paves the way for peace and tensions decline (Jakson \& Sørensen, 2013). However, the EU-Russia energy relation has stayed on a rudimentary dependency level. In fact, interdependency has not worked since each side has been worried that the future interdependence will become asymmetrical. Therefore, none of the sides "can reduce their own dependence without also threatening to increase the dependence of the other side and as a result, the relationship looks like a classic security dilemma - where neither side can improve its own security without threatening the security of the other side" (Krickovic, 2015). 


\subsubsection{Alternatives for Russian gas}

In the previous sector, it was shown that Russian gas is not such a threat that a severe restraining action plan would have to be demanded. From a different angle, we can pose the question that if the EU repeals Russian gas then what alternatives will be available. However, there is another fact beyond this question: European conventional gas production from Norway, Netherlands, and the UK is expected to fall by $110 \mathrm{bcm} /$ year (or by 40\%) in the period 2013-2030 (Dickel et al., 2014), as EU domestic production has already started to fall from the beginning of the 2000s. Since 2001, EU-28's natural gas production decreased by $38 \%$ while consumption was reduced by only about $7 \%$ (Demiryol, 2014). Therefore, EU's gas needs for import are going to grow and new sources are not just required for "diversification" but also for "compensation". According to the International Energy Agency projection, the gap between EU's natural gas demand and supply will be between 350-400 billion cubic meters annually in the approaching decade. Generally, while Iran and the US Liquefied Natural Gas (LNG) are counted as external potential resources, European unconventional (shale gas, tight gas, and coal bed methane) resources and biogas are considered potential domestic resources.

Although Iran is the first gas owner in the world, it is not among the top ten gas exporters (BP, 2018). Therefore, the required exportation infrastructures, including LNG terminals and pipelines, are not in place yet. Interval disruptions in Iranian gas exporting to Turkey in 2002, 2004, 2005, 2006, 2007 and 2008 due to different technical issues and sabotage (Kinnander, 2010) have made Iran suspicious as a reliable exporter and political obstacles between Tehran and the Western world hinder any effort to execute the idea of gas transfer.

Moreover, different proposed routes to transport Iranian gas to Europe are problematic. The pricing conflict between Iran and Turkey makes Iran's participation in the Trans Anatolian Pipeline (TANAP) unlikely. A hypothetical extra pipeline through Turkey needs in excess of 5 billion dollars (Rezayeva, 2014), raised a lot of questions regarding the financing of the pipeline considering the US sanctions and the low gas price makes the project economically doubtful. The same applies to the northern route through the Caucasus region and the Black Sea bed. The other already proposed Friendship pipeline via Iraq and Syria does not seem promising considering the Syrian civil war. After the US withdrawal from the Iranian nuclear deal, the political aggression and sanctions have intensified against Iran. Thus, it is more difficult to cooperate with Iran on LNG facilities and therefore, this option is not achievable either. 
Although the US has become a natural gas net exporter thanks to the shale gas boom and it is estimated that it will be ranked among top three LNG exporters, until 2030 (BP, 2019), the US LNG is not promising to penetrate into the whole EU market, at least in the short term perspective. This is due to lack of interconnectors between existing LNG terminals and final customers, lack of reverse flow through EU natural gas network and the fact that the US LNG is more expensive than Russian gas (Bros, 2017). Going forward, LNG imports in Europe will have to compete on a cost basis with existing and new pipeline supplies of natural gas, particularly from Russia. As a result, it is not so likely to see that all of Europe can or is inclined to take advantage of the US gas, but maybe just the Eastern and particularly the Baltic region (Dickel et al., 2014). It is also contemplative that current US efforts for halting NS2 are more political and can be associated with the interests of the US to find a market for its own LNG as it was already stated by Austrian Chancellor Christian Kern and German Foreign Minister Sigmar Gabriel (Anon., 2017).

From the other perspective, the statistics of gas export from Norway- the major European gas producer - shows that Germany (29.7), the UK (28.7), and Netherlands (18.6) are the main importers out of the total (109.8 billion cubic meters, bcm) Norwegian gas export volume (BP, 2018). Taking into account that Netherlands and the UK will face a sharp decline in their domestic production, and the fact that Norway will face almost $30 \mathrm{bcm}$ decline in gas production until 2030 (Hall, 2018), the US LNG will suit mainly this region. Therefore, even natural gas production dynamics of Europe shows that the US LNG will not be enough to make a huge impact in the European market. Moreover, as the Eastern Asian LNG market has always been more enticing for producers, a part of the US LNG will be expected to go towards the Asian destination, which leaves it out of reach for the EU.

When it comes to renewable domestic resources, statistics show that the outlook for (renewable) biogas is more optimistic with a possible increase from $14 \mathrm{bcm}$ in 2012 to $28 \mathrm{bcm}$ in 2020, and perhaps to $50 \mathrm{bcm}$ in 2030, although problems of subsidy make the larger figures uncertain. Therefore, it seems likely that Europe will only be able to replace at most around half of the decline in conventional gas with unconventional/renewable production (Dickel et al., 2014).

Recapping the main points of the alternatives for Russian gas, considering the declining European domestic gas production and political restrictions for the alternatives (mainly Iran) or economic considerations of the US LNG, Russian gas will still be needed as much until 2030. Moreover, the new alternative resources including renewables cannot compensate for this decline. In this 
situation, severe efforts to curtail Russian gas-including amendment in Gas Directive for hindering NS2 — will not enhance EU's energy security.

The results of the political analysis show that Russia is not always able to threaten the EU with the "energy weapon". This is because possessing energy resources generally does not result in the ability to take advantage of the relationship on the exporter's side. In fact, Russia's ability to use its energy resource as a weapon against the EU is restrained by different factors, including its tendency to preserve the face of a reliable supplier in the EU's natural gas market and the essence of Russia-EU interdependency relation. Western sanctions have also restrained Russia's maneuverability.

\section{Conclusion}

In this research, the outcomes of the proposed amendment of the Gas Directive on the EU's energy security have been surveyed by analyzing the effects of the amendment on energy security elements from the legal and political perspective. It is critical to assess this impact because the main goal of the amendment is curtailment of NS2 in order to preserve the Union's energy security, however, since the amendment affects other suppliers adversely, it will threaten the energy security.

The results of the analysis show that the proposed amendment by the Commission will not lead to higher energy security, because it will increase the uncertainty for the energy investors considering its retroactive and ambiguous approach, which affects the existing and under-construction pipelines. Therefore, the sustainability of energy supply to EU is being jeopardized, which means that 'acceptability' is threatened. Moreover, it will restrain Russian gas, while there are no reliable and affordable gas resources for the EU to compensate it with and this is against the 'affordability' of energy supply. The amendment defies 'accessibility' as one of the other components of energy security. Thus, if energy security, as providing available, accessible, affordable and acceptable energy, is challenged, the EU's decision for the Gas Directive amendment is harmful to the Union's energy security. In fact, the Commission has legislated a package to counteract the threat coming from the 'securitized' Russian gas, while the amendment has become a threat for EU's energy security per se.

Last but not least. NS2 is still a controversial issue and the amendment has not been ratified in the European Parliament yet. Therefore, it may be revised again 
in the Parliament, particularly if it is postponed to the next European Parliament, which may have different priorities and orientations. In addition, the Danish government's decision on issuance of permission for the pipeline may impact the whole story. And, finally, the upcoming decisions by Germany, Russia and the United States on NS2 should be considered in the analysis. Therefore, since the impacts of influencing actors are still unclear, the study can be followed and fulfilled in the future according to the actors' upcoming decisions.

\section{Acknowledgments}

I would like to thank the European Regional Development Fund's programme Dora Pluss Activity 2.1 for the grant during my studies. In addition, I would like to thank Associate Prof. Holger Mölder and Prof. Katrin Nyman-Metcalf for their kind advice.

Javad Keypour is a natural gas market analyst at the ATEF think tank, Tehran, Iran and a doctoral student at the Tallinn University of Technology, Estonia. He is also editor-in-chief for The Energy Diplomacy Journal, published in Iran. Javad has worked for Iranian Vice Presidency for Science and Technology office for five years as expert in energy market. He received his bachelor's degree from the Tehran Polytechnic in 2008 and MSc in 2011. His major research focus are EU-Russia energy relations, natural gas market analysis and the Middle East politics.

\section{References}

Aalto, P. (2016), 'Modernisation of the Russian energy sector: constraints on utilising Arctic offshore oil resources,' Europe-Asia Studies, vol. 68, no. 1, pp. 38-63. https://doi.org/10.1080/09668136.2015.1113509

Anon. (2017), 'Austrian Chancellor says new US sanctions against Russia 'unacceptable', Sputnik News Agency, 27 July. Retrieved from https://sputniknews.com/ politics/201707271055914177-austria-russian-sanctions-unacceptable/ [accessed 26 Mar 2019]

Belyi, A. (2003), 'New dimensions of energy security of the enlarging EU and their impact on relations with Russia,' European Integration, vol. 25, no. 4, pp. 351-369. https://doi.org/10.1080/0703633032000163193 
Bergström, S. C. (2010), Lonely and Hardworking, Oslo: University of Oslo.

Boussena, S. \& Locatelli, C. (2013), 'Energy institutional and organisational changes in EU and Russia: Revisiting gas relations,' Energy Policy, vol. 55, pp. 180-189. https://doi.org/10.1016/j.enpol.2012.11.052

BP (2018), BP Statistical Review of World Energy, London: Pureprint.

BP (2019), BP Energy Outlook, London: BP p.l.c.

Bros, T. (2017), The U.S. LNG vs Russian Pipe Gas: Impact on Price, St. Petersburg: Oxford Institute for Energy Studies.

Buzan, B.; Waver, O. \& Wilde, J. D. (1998), Security: A New Framework for Analysis, London: Lynne Rienner Publishers.

Chernyak, O.; Kharlamova, G. \& Stavytskyy, A. (2018), 'Trends of international energy security risk index in European countries,' Baltic Journal of European Studies, vol. 8, no. 1, pp. 5-32. https://doi.org/10.1515/bjes-2018-0002

Coq, C. L. \& Paltseva, E. (2009), 'Measuring the security of external energy supply in the European Union,' Energy Policy, vol. 37, no. 11, pp. 4474-4481. https://doi.org/10.1016/j.enpol.2009.05.069

Demiryol, T. (2014), 'The Eastern Partnership and the EU-Turkey energy relations,' Baltic Journal of European Studies, vol. 4, no. 2, pp. 50-68. https://doi.org/10.2478/bjes-2014-0015

Dickel, R. et al. (2014), Reducing European Dependence on Russian Gas: Distinguishing Natural Gas Security from Geopolitics, 1st ed., Oxford: Oxford Institute for Energy Studies.

EIA (2017), Country Analysis Brief: Russia, Washington, DC: Energy Information Administration.

Eurostat (2018), Energy Dependence by Product. Retrieved from https://ec.europa.eu/ eurostat $/ \operatorname{tgm} /$ refreshTableAction.do?tab $=$ table\&plugin $=1 \&$ pcode $=$ sdg_07_50\&la nguage $=$ en [accessed 26 March 2019]

Farchy, J. (2014), 'Russian oil: between a rock and a hard place,' Financial Times, 29 October. Retrieved from https://www.ft.com/content/fc354a6a-5dcb-11e4-b7a200144feabdc0 [accessed 26 Mar 2019]

Funtini, F. (2015), Third Energy Package, Padua: Leonardo ENERGY.

Gazprom (2015), Gazprom Company. Retrieved from www.gazpromexport.ru [accessed 22 Mar 2019]

Gibbs, G. R. (2008), Analysing Qualitative Data, London: SAGE. https://doi.org/10.4135/9781849208574

Goldthau, A. \& Sitter, N. (2014), 'A liberal actor in a realist world? The Commission and the external dimension of the single market for energy,' Journal of European Public Policy, vol. 21, no. 10, pp. 1452-1472.

https://doi.org/10.1080/13501763.2014.912251 
Guest, G.; Mac Queen, K. M. \& Namey, E. E. (2012), Applied Thematic Analysis, Thousand Oaks: SAGE Publications. https://doi.org/10.4135/9781483384436

Gurvich, E. \& Prilepskiy, A. (2015), 'The impact of financial sanctions on the Russian economy,' Russian Journal of Economics, vol. 1, no. 4, pp. 359-385. https://doi.org/10.1016/j.ruje.2016.02.002

Hall, M. (2018), Norwegian Gas Exports: Assessment of Resources and Supply to 2035, 1st ed., Oxford: Oxford Institute for Energy Studies. https://doi.org/10.26889/9781784671037

Hancher, L. \& Marhold, A. (2019), A common EU framework regulating import pipelines for gas? : exploring the Commission's proposal to amend the 2009 gas directive,' Journal of Energy \& Natural Resources Law, vol. 37, no. 2, pp. 1-15. https://doi.org/10.1080/02646811.2019.1569873

Henderson, J. (2015), 'Russia's changing gas relationship with Europe,' Russian Analytical Digest, vol. 12, no. 163, pp. 2-6.

Högselius, P. (2013), Red Gas: Russia and the Origins of European Energy Dependence, 1st ed., New York: Palgrave Macmillan.

Huysmans, J. (1998), 'Revisiting Copenhagen: or, on the creative development of a security studies agenda in Europe,' European Journal of International Relations, vol. 4, no. 4, pp. 479-505. https://doi.org/10.1177/1354066198004004004

Jakson, R. \& Sørensen, G. (2013), Introduction to International Relations: Theories and Approaches, 5th ed., Oxford: Oxford University Press.

Kerikmäe, T. (2000), Euroopa Liit ja õigus [European Union and Law], 1st ed., Tallinn: Õiguskirjastus.

Kerikmäe, T. (2006), European Union and Law: Summary of the Monograph (Analytical Overview), Presented as $\mathrm{PhD}$ thesis, Tallinn: International University Audentes.

Kinnander, E. (2010), The Turkish-Iranian Gas Relationship: Politically Successful, Commercially Problematic, 1st ed., Oxford: Oxford Institute for Energy Studies.

Krickovic, A. (2015), 'When interdependence produces conflict: EU-Russia energy relations as a security dilemma,' Contemporary Security Policy, vol. 36, no. 1, pp. 3-26. https://doi.org/10.1080/13523260.2015.1012350

Lifan, L. \& Chengzhi, W. (2015), 'Energy cooperation between China and Russia: uncertainty and prospect of development,' Russian Analytical Digest, 24 February, pp. 11-14.

Maleki, A. (2017), Energy Security, 1st ed., Tehran: Donya-e-Eghtesad.

Minfin (2019), Annual report on execution of the federal budget (starting from January 1, 2006). Ministry of Finance of the Russian Federation. Retrieved from https:// www.minfin.ru/en/statistics/fedbud/ [accessed 23 Mar 2019]

Mitrova, T. (2018), 'Western sanctions on Russia's oil and gas sector: a damage assessment,' Carnegie Moscow Centre. Retrieved from https://carnegie.ru/ commentary/76909 [accessed 23 Mar 2019] 
Morbee, J. \& Proost, S. (2010), 'Russian gas imports in Europe: how does Gazprom reliability change the game?' The Energy Journal, vol. 31, no. 4, pp. 79-109. https://doi.org/10.5547/ISSN0195-6574-EJ-Vol31-No4-4

Nikulina, A. Y. \& Kruk, M. N. (2016), 'Impact of sanctions of European Union and Unites States of America on the development of Russian oil and gas complex,' International Journal of Economics and Financial Issues, vol. 6, no. 4, pp. 1379-1382.

Özcan, S. (2013), 'Securitization of energy through the lenses of Copenhagen School,' The 2013 WEI International Academic Conference Proceedings, Orlando: West East Institute, pp. 8-9.

Proposal (6351/19/COR1) for a Directive of the European Parliament and of the Council amending Directive 2009/73/EC concerning common rules for the internal market in natural gas, 19.02.2019.

Ratcliffe, V. (2018), 'Gas flows on Medgaz and Greenstream pipelines,' Interfax Global Energy. Retrieved from http://interfaxenergy.com/article/32665/gas-flows-fall-onmedgaz-and-greenstream-pipelines [accessed 23 Mar 2019]

Rezayeva, G. (2014), Natural Gas in Turkish Domestic Energy Market: Policies and Challenges, 1st ed., Oxford: Oxford Institute for Energy Studies. https://doi.org/10.26889/9781907555930

Romanova, T. (2016), 'Is Russian energy policy towards the EU only about geopolitics? The case of the Third Liberalisation Package,' Geopolitics, vol. 21, no. 4, pp. 857-879. https://doi.org/10.1080/14650045.2016.1155049

Ruban, R. (2013), The European Natural Gas Supply, under Particular Consideration of Gas Transit, 1st ed., Berlin: viademica.verlag berlin.

Russell, M. (2016), 'Sanctions over Ukraine: Impact on Russia,' European Parliament Think Tank Briefing, 17 January, Brussels: European Parliamentary Research Service (EPRS).

Siddi, M. (2018), 'The role of power in EU-Russia energy relations: the interplay between markets and geopolitics,' Europe-Asia Studies, vol. 70, no. 10, pp. 1552-1557. https://doi.org/10.1080/09668136.2018.1536925

Smith, K. C. (2009), Security Implications of Russian Energy Policies, Brussels: Centre for European Policy Studies.

Sorrell, S. (2007), 'Improving the evidence base for energy policy: the role of systematic reviews,' Energy Policy, vol. 35, no. 3, pp. 1858-1871. https://doi.org/10.1016/j. enpol.2006.06.008

Sovacool, B. K. (2011), The Routledge Handbook of Energy Security, 1st ed., Oxford: Routledge. https://doi.org/10.4324/9780203834602

Stegen, K. S. (2011), 'Deconstructing the "energy weapon": Russia's threat to Europe as case study,' Energy Policy, vol. 39, no. 10, pp. 6505-6513.

https://doi.org/10.1016/j.enpol.2011.07.051 
Talus, K. (2017), 'Application of EU energy and certain national,' Journal of World Energy Law and Business, vol. 10, no. 1, pp. 30-42. https://doi.org/10.1093/jwelb/jwx027

Talus, K. (2019), 'EU gas market amendment-despite of compromise, problems remain,' Oil, Gas \& Energy Law Intelligence, 19 February.

Tomić, B. (2018), 'Update: European Parliament calls for Nord Stream 2 pipeline project to be stopped,' Offshore Energy Today. Retrieved from https://www. offshoreenergytoday.com/european-parliament-calls-for-nord-stream-2-pipelineproject-to-be-stopped/ [accessed 5 May 2019]

Vaismoradi, M.; Turunen, H. \& Bondas, T. (2013), 'Content analysis and thematic analysis: implications for conducting a qualitative descriptive study,' Nursing and Health Sciences, vol. 15, no. 3, pp. 398-405. https://doi.org/10.1111/nhs.12048

Wilson, A. B. (2017), New Rules on Security of Gas Supply, Brussels: EU Parliament.

Wilson, A. B. (2018), Common Rules for Gas Pipelines Entering the EU Internal Market, Brussels: European Parliamentary Research Service.

Yafimava, K. (2017), The Council Legal Service's Assessment of the European Commission's Negotiating Mandate and What It Means for Nord Stream 2, Oxford: Oxford Institute for Energy Studies.

Zbytniewska, K. (2019), 'Jerzy Buzek: Deal on Nord Stream 2 is good for Poland and EU,' Euractiv, 13 February (Updated 17 February). Retrieved from https:// www.euractiv.com/section/energy/interview/jerzy-buzek-deal-on-nord-stream-2is-good-for-poland-and-eu/ [accessed 26 Mar 2019] 